Marquette University

e-Publications@Marquette

$11-8-2016$

\title{
Critical Role of the Secondary Binding Pocket in Modulating the Enzymatic Activity of DUSP5 toward Phosphorylated ERKs
}

Marat R. Talipov

Marquette University

Jaladhi Nayak

Medical College of Wisconsin

Michael Lepley

Medical College of Wisconsin

Robert D. Bongard

Medical College of Wisconsin

Daniel Sem

Marquette University, daniel.sem@marquette.edu

See next page for additional authors

Accepted version. Biochemistry, Vol. 55, No. 43 (November 8, 2016): 6187-6195. DOI. (C) 2016 American Chemical Society. Used with permission. 
Authors

Marat R. Talipov, Jaladhi Nayak, Michael Lepley, Robert D. Bongard, Daniel Sem, Ramani Ramchandran, and Rajendra Rathore 


\title{
Critical Role of the Secondary Binding Pocket in Modulating the Enzymatic Activity of DUSP5 toward Phosphorylated ERKs
}

\author{
Marat R. Talipov \\ Department of Chemistry, Marquette University, Milwaukee, WI \\ Jaladhi Nayak
}

Department of Pediatrics, Department of Obstetrics and Gynecology, Children's Research Institute (CRI) Developmental Vascular Biology Program, and Translational and Biomedical Research Center, Medical College of Wisconsin, Milwaukee, WI

Michael Lepley

Department of Pediatrics, Department of Obstetrics and Gynecology, Children's Research Institute (CRI) Developmental Vascular Biology Program, and Translational and Biomedical

Research Center, Medical College of Wisconsin, Milwaukee, WI

Robert D. Bongard

Center for Structure-based Drug Design and Development, Department of Pharmaceutical Sciences, Concordia University of Wisconsin, Mequon, WI

Daniel S. Sem

Center for Structure-based Drug Design and Development, Department of Pharmaceutical Sciences, Concordia University of Wisconsin, Mequon, WI

\section{Ramani Ramchandran}

Department of Pediatrics, Department of Obstetrics and Gynecology, Children's Research Institute (CRI) Developmental Vascular Biology Program, and Translational and Biomedical

Research Center, Medical College of Wisconsin, Milwaukee, WI

Rajendra Rathore

Department of Chemistry, Marquette University, Milwaukee, WI

Biochemistry, Vol. 55, No. 44 (November 8, 2016): pg. 6187-6195. DOI. This article is @ American Chemical Society and permission has been granted for this version to appear in e-Publications@Marquette. American Chemical Society does not grant permission for this article to be further copied/distributed or hosted elsewhere without the express permission from American Chemical Society. 
NOT THE PUBLISHED VERSION; this is the author's final, peer-reviewed manuscript. The published version may be accessed by following the link in the citation at the bottom of the page.

Abstract: DUSP5 is an inducible nuclear dual-specificity phosphatase that specifically interacts with and deactivates extracellular signal-regulated kinases ERK1 and ERK2, which are responsible for cell proliferation, differentiation, and survival. The phosphatase domain (PD) of DUSP5 has unique structural features absent from other nuclear DUSPs, such as the presence of a secondary anion-binding site in the proximity of the reaction center and a glutamic acid E264 positioned next to the catalytic cysteine C263, as well as a remote intramolecular disulfide linkage. The overall 400 ns molecular dynamics simulations indicate that the secondary binding site of DUSP5 PD acts as an allosteric regulator of the phosphatase activity of DUSP5. Our studies have identified E264 as a critical constituent of the dual binding pocket, which regulates the catalytic activity of DUSP5 by forming a salt bridge with arginine R269. Molecular dynamics studies showed that initial occupation of the secondary binding pocket leads to the breakage of the salt bridge, which then allows the occupation of the active site. Indeed, biochemical analysis using the pERK assay on mutant E264Q demonstrated that mutation of glutamic acid E264 leads to an increase in the DUSP5 catalytic activity. The role of the secondary binding site in assembling the DUSP5-pERK pre-reactive complex was further demonstrated by molecular dynamics simulations that showed that the remote C197-C219 disulfide linkage controls the structure of the secondary binding pocket based on its redox state (i.e., disulfide/dithiol) and, in turn, the enzymatic activity of DUSP5.
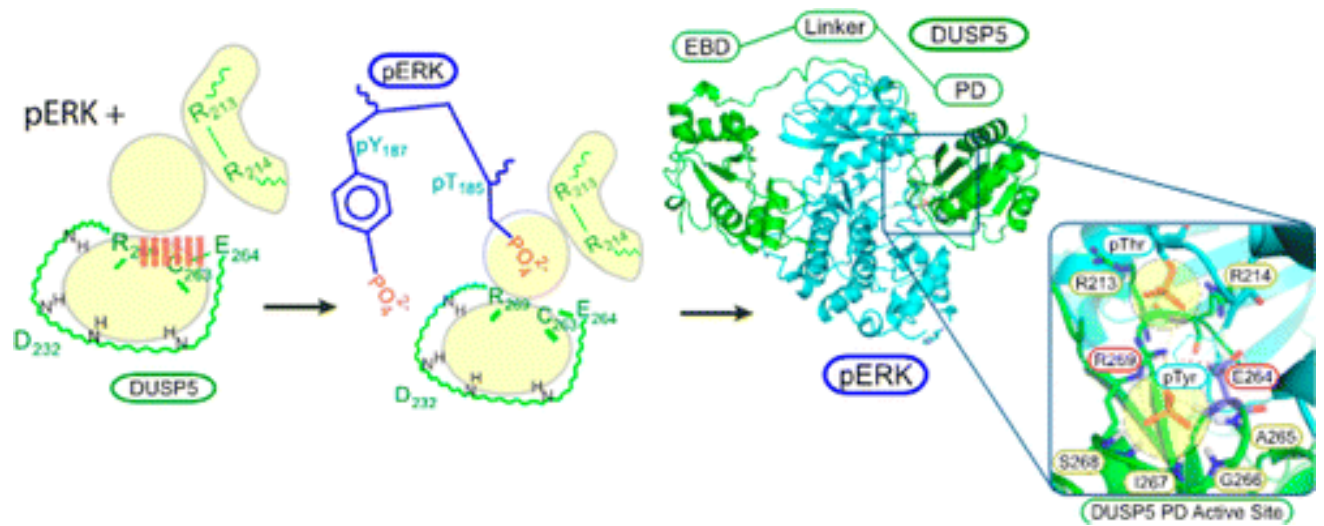

Mitogen-activated protein kinases (MAPKs) determine physiological and pathological responses to a diverse array of extracellular and intracellular stimuli and regulate cell proliferation, gene expression, mitosis, and other cellular functions. $\frac{1-3}{}$ Tight spatial and temporal control of MAPK signaling is maintained by dual-specificity MAPK phosphatases (DUSPs), $\frac{4-7}{4}$ which deactivate MAPKs through dephosphorylation of serine/threonine and tyrosine residues in their activation loops. DUSPs represent a desirable target for drug development because their expression is regulated both spatially and temporally, in contrast with ubiquitous MAPKs. $\frac{15}{1}$ The active site of the phosphatase domain of DUSPs contains a highly conserved HCXXGXXRS motif (Table 1), (8) in which the cysteine residue serves as an enzymatic nucleophile. The arginine residue [e.g., R269 in DUSP5 (Figure 1)] and the backbone serve to stabilize the phosphoryl group during its transfer from phosphorylated Thr/Ser or Tyr to cysteine, which is followed by transfer of a proton from a highly conserved aspartic acid to the resulting phenolate anion (Figure 1)..$\underline{89}$

Biochemistry, Vol. 55, No. 44 (November 8, 2016): pg. 6187-6195. DOI. This article is (c) American Chemical Society and permission has been granted for this version to appear in e-Publications@Marquette. American Chemical Society does not grant permission for this article to be further copied/distributed or hosted elsewhere without the express permission from American Chemical Society. 


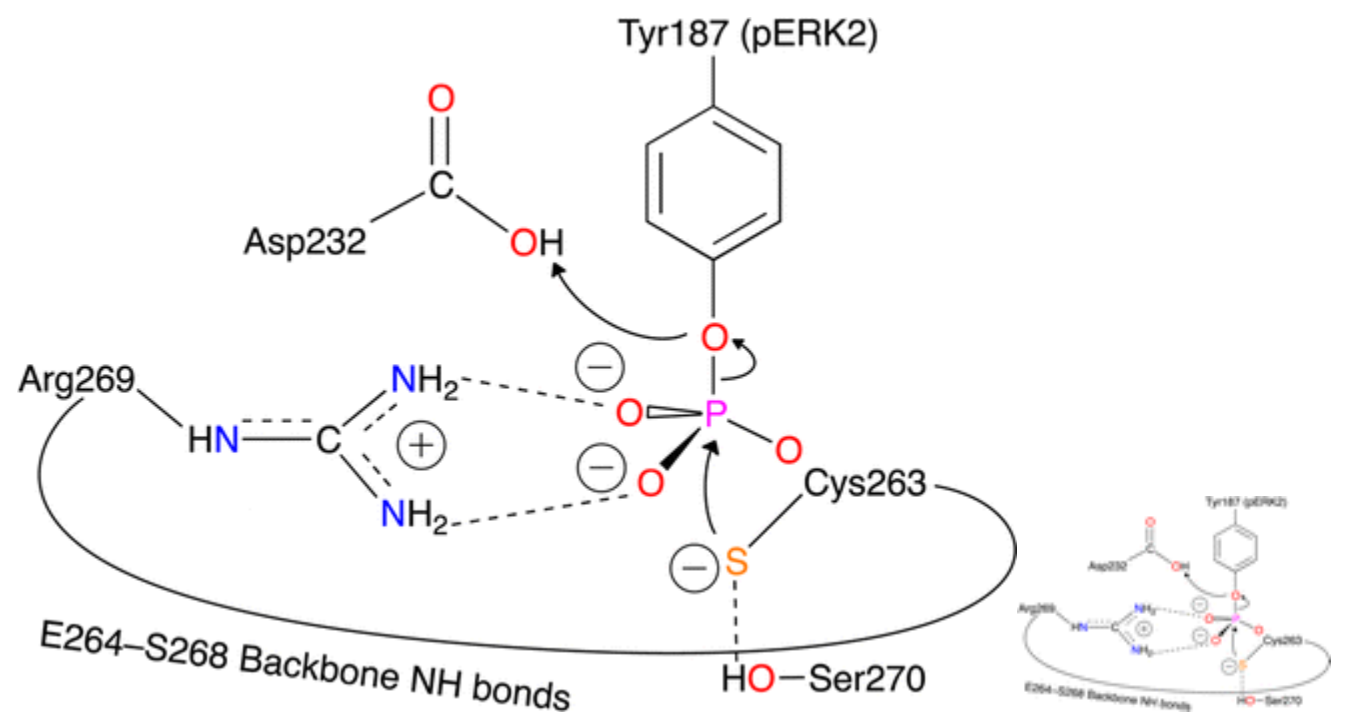

Figure 1. Composition of the active site of the phosphatase domain (PD) of DUSP5 and the mechanism showing phosphorylation of Cys263 (PD DUSP5) by Tyr187 (pERK2).

Table 1. Summary for the Typical Human DUSPs That Target ERK1/2 as a Substrate

\begin{tabular}{|c|c|c|c|c|c|c|}
\hline other names & $\begin{array}{c}\text { cellular } \\
\text { localization }\end{array}$ & $\begin{array}{l}\text { Uniprot } \\
\text { code }\end{array}$ & $\begin{array}{l}\text { active site } \\
\text { sequence }\end{array}$ & PDB entry & $\begin{array}{l}R_{\mathrm{AS}-\mathrm{SB}} \\
(\AA) \underline{\mathrm{a}}\end{array}$ & $\begin{array}{c}N_{S-} \\
s^{\underline{b}}\end{array}$ \\
\hline $\begin{array}{r}\text { DUSP1 CL100, MKP1, } \\
\text { PTPN10, VH1 }\end{array}$ & nuclear & P28562 & HCQAGISR & - & - & - \\
\hline DUSP2 PAC1 & nuclear & Q05923 & HCQAGISR & $\underline{1 M 3 G(18)}$ & 15 & - \\
\hline DUSP4 MKP2, VH2 & nuclear & Q13115 & HCQAGISR & $\underline{3 E Z Z(19)}$ & 25 & - \\
\hline DUSP5 hVH3, VH3 & nuclear & Q16690 & HCEAGISR & $\underline{2 G 6 Z(16)}$ & 7 & 1 \\
\hline DUSP6 MKP3, PYST1, rVH-6 & cytoplasm & Q16828 & HCLAGISR & $\underline{1 \mathrm{MKP}(17)}$ & - & - \\
\hline DUSP7 PYST2, MKPX & cytoplasm & Q16829 & HCLAGISR & - & - & - \\
\hline DUSP9 MKP4 & cytoplasm & Q99956 & HCLAGISR & $\underline{2 \mathrm{HXP}(20)}$ & - & - \\
\hline
\end{tabular}

aDistance between the active site and the second anion-binding site.

bNumber of disulfide bonds in the phosphatase domain.

The Ramchandran group recently demonstrated that one of the members of the DUSP family, DUSP5, plays a critical role in vascular development and disease. $\underline{10}$ Being an inducible nuclear phosphatase, DUSP5 selectively interacts with and deactivates ERK1 and ERK2 MAPKs, which are responsible for cell proliferation, differentiation, and survival,,$\underline{13}$ but not other MAPKs such as JNK and p38.11,12 Selectivity of DUSP5 toward phosphorylated ERK2 (pERK2) is governed by the structural composition of DUSP5 that consists of two globular domains, ERK-binding domain (EBD) and phosphatase domain (PD), connected by an $~ 40$-amino acid linker, which help appose the active site of PD DUSP5 to the phosphorylated residues of pERK2. 14 The phosphorylated form of ERK (pERK) induces expression of DUSP5, and thus, pERK signaling is self-regulated via the DUSP5 negative

Biochemistry, Vol. 55, No. 44 (November 8, 2016): pg. 6187-6195. DOI. This article is (C American Chemical Society and permission has been granted for this version to appear in e-Publications@Marquette. American Chemical Society does not grant permission for this article to be further copied/distributed or hosted elsewhere without the express permission from American Chemical Society. 
feedback loop. However, a detailed mechanistic understanding of the interaction of MAPK phosphatases with MAPKs $\underline{15}$ and, in particular, of DUSP5, which interacts specifically with pERK2, is lacking.

It is noted that the PD of DUSP5 has unique features not present in other human DUSPs active toward ERK (Table 1), which we will illustrate for the example of closely structurally and funcionally related cytoplasmic DUSP6, which is also highly specific to ERK1/2 and does not interact with other MAPKs. For example, (1) DUSP5 has a preassembled active site configuration with the catalytic aspartic acid positioned in the proximity of the reaction center \{i.e., a distance of $4.8 \AA$ between the carboxyl carbon atom of the aspartic acid and a sulfate anion found in the active site in the X-ray structure of the DUPS5 PD [Protein Data Bank (PDB) entry 2G6Z16] \}. In contrast, DUSP6's catalytic aspartic acid is separated by $9.7 \AA$ from the chloride anion present in the active site in its X-ray structure (PDB entry $\underline{1 \mathrm{MKP}}) \cdot \underline{17}$ It is also noted that unlike DUSP5, DUSP6 attains a reactive conformation only upon binding to ERK.17 (2) The DUSP5 PD contains a secondary anionbinding site in the proximity to the reaction center (i.e., active site). The presence of the secondary binding site in the DUSP5 PD was discerned by X-ray crystallography of the DUSP5 PD, which showed the presence of a pair of sulfate anions occupying the active site as well as secondary binding site (PDB entry 2G6Z16). The separation between these sulfate anions was found to be $7.3 \AA$ (Table 1). (3) The DUSP5 PD has an internal disulfide bond

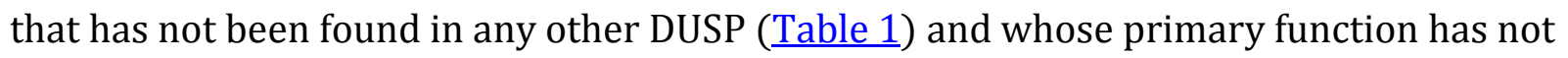
yet been elucidated. (4) Although all DUSPs in Table 1 have a highly conserved active site primary sequence HCXAGISR, the active site of DUSP5 has a glutamic acid (X $=\mathrm{E}$ ) positioned next to the catalytic cysteine, whereas other ERK-selective human DUSPs have either leucine $(X=L)$ or glutamine $(X=Q)$ at this position.

Comparison of the reported Michaelis-Menten parameters for DUSP5 using the $p$ nitrophenyl phosphate (pNPP) assay with those previously published for DUSP6 and DUSP3 (Table S1) identified DUSP5 as the least reactive phosphatase toward pNPP $\left(k_{\text {cat }}=\right.$ $6.0 \times 10^{-6} \mathrm{~s}^{-1}$ vs values of $0.1-3.3$ and $1.7 \mathrm{~s}^{-1}$ for DUSP5 vs DUSP6 and DUSP3, respectively). This finding is surprising in light of the fact that DUSP 5 has a preassembled active site, whereas DUSP6, for example, undergoes conformational reorganization into the active form upon interaction with ERK2. Moreover, even the inactive form of DUSP6 is several orders of magnitude more active $\left(k_{\text {cat }}=0.6-1.2 \times 10^{-2} \mathrm{~s}^{-1}\right)$ than DUSP5 $\left[k_{\text {cat }}=6.0 \times 10^{-6} \mathrm{~s}^{-}\right.$ 1 (see Table S1)].

Biochemistry, Vol. 55, No. 44 (November 8, 2016): pg. 6187-6195. DOI. This article is @ American Chemical Society and permission has been granted for this version to appear in e-Publications@Marquette. American Chemical Society does not grant permission for this article to be further copied/distributed or hosted elsewhere without the express permission from American Chemical Society. 
Accordingly, in this study, we questioned if the low catalytic activity of DUSP5 as compared with those of other DUSPs is related to its unique structural features such as the presence of two proximal binding pockets and an additional disulfide linkage. To investigate this question, we performed a detailed molecular dynamics investigation together with the preparation of DUSP5 point mutants E264Q, E264L, and R214Q and analysis of their activities in comparison with the wild-type DUSP5 using pERK2 as a substrate. The computational/experimental results presented herein reveal the intimate involvement of the proximal binding pocket in the formation of the DUSP5-pERK2 prereactive complex. Glutamic acid E264, which lies at the interface between the two binding pockets, plays a critical role in allosteric regulation of the initial binding event and thereby modulates the catalytic activity of DUSP5. Additionally, a remote disulfide linkage (C197C219) modulates the catalytic activity of DUSP5 whose redox state (i.e., disulfide/dithiol) exerts control on the structure of the secondary binding pocket. The details of these findings are discussed herein.

\title{
Materials and Methods
}

\author{
Computational Details
}

Molecular dynamics simulations were performed using YASARA Structure version 13.9.8 $\stackrel{21,22}{2}$ with the Amber 03 force field (which has parameters identical to those of the "ff03" force field used in Amber) $\underline{23}$ with a $7.86 \AA$ A force cutoff, while the particle mesh Ewald algorithm $\underline{24}$ was used to treat long-range electrostatic interactions without a distance cutoff. A simulation cell was defined to be cubic with periodic boundary conditions in all directions, with a distance of at least $10 \AA$ from boundary to protein along each axis. The simulation box was filled with TIP3P water $\underline{25}$ at a density of $0.997 \mathrm{~g} / \mathrm{mL}$ and $\mathrm{Na}^{+}$and $\mathrm{Cl}^{-}$ ions, which were placed at the lowest and highest electrostatic potential locations, respectively, to neutralize the cell and approximate the physiological saline solution $(0.9 \%$ $\mathrm{NaCl}$ ). To remove bumps and correct the covalent geometry, the structure was energyminimized by a short steepest descent minimization, followed by simulated annealing (time step of $2 \mathrm{fs}$, atom velocities scaled down by 0.9 every 10 th step) until convergence was reached, i.e., until the energy improved by $<0.05 \mathrm{~kJ} / \mathrm{mol}$ per atom over 200 steps. The resulting structure was used as a starting point for molecular dynamics simulations using the NPT ensemble, which were performed at $298 \mathrm{~K}, 1$ bar, and pH 7.4, with a time step of 1.25 fs for intramolecular interactions and 2.5 fs for intermolecular interactions. $\underline{26}$ Atomic velocities were rescaled using the modified Berendsen thermostat, based on time-averaged temperatures, which does not depend on the strongly fluctuating instantaneous

Biochemistry, Vol. 55, No. 44 (November 8, 2016): pg. 6187-6195. DOI. This article is (C American Chemical Society and permission has been granted for this version to appear in e-Publications@Marquette. American Chemical Society does not grant permission for this article to be further copied/distributed or hosted elsewhere without the express permission from American Chemical Society. 
microscopic temperature. 27 The pressure during the molecular dynamics (MD) simulations was controlled using the time-averaged solvent density as a probe for the pressure in the box, and the cell was resized isotropically to maintain the target solvent density and pressure. Initial structures for the molecular dynamics simulations were obtained from the X-ray crystal structure of the DUSP5 PD (PDB entry $\underline{2 \mathrm{G} 6 \mathrm{Z}^{16}}$ ). The preliminary MD simulations of the DUSP5 PD/solvent/counterion system were performed by heating the system to $600 \mathrm{~K}$ with a subsequent 100 ps equilibration, which did not alter the secondary structure of the PD in any significant way. The sample structures that resulted from this simulation were used as starting geometries for the four independent $100 \mathrm{~ns}$ MD simulations at $300 \mathrm{~K}$. The statistical data from these trajectories were combined (total a sampling time of $400 \mathrm{~ns}$ ) to provide the distance distribution histograms presented in Figures 3 and $\underline{9}$ (see Table S1 and Figures S1 and S2 for the MD simulation details).

Site-Directed Mutagenesis

We generated point mutants E264L, E264Q, and R214Q using the QuikChange Lightning Site-Directed Mutagenesis Kit (Agilent Technologies). All mutations were created on the wild-type (WT) DUSP5 backbone construct that was cloned into the pGEX-6P1 expression vector (GE Healthcare). The reaction mixture contained 25 ng of plasmid DNA (GST-DUSP5), $2.5 \mu \mathrm{L}$ of $10 \times$ reaction buffers, $0.5 \mu \mathrm{L}$ of dNTP mix, $0.75 \mu \mathrm{L}$ of QuikSolution reagent with $62.5 \mathrm{ng}$ of forward and reverse primers, and $0.5 \mu \mathrm{L}$ of QuikChange Lightning enzyme. Polymerase chain reactions (PCRs) for single-point mutations were run for initial denaturation for $2 \mathrm{~min}$ at $95^{\circ} \mathrm{C}, 18$ cycles of $20 \mathrm{~s}$ at $95^{\circ} \mathrm{C}, 15 \mathrm{~s}$ of the gradient annealing temperature at $60-68{ }^{\circ} \mathrm{C}$, and $180 \mathrm{~s}$ at $68^{\circ} \mathrm{C}$, followed by final extension for $5 \mathrm{~min}$ at $68^{\circ} \mathrm{C}$ (C1000 thermal cycler). The resultant PCR mixture was incubated at $37^{\circ} \mathrm{C}$ for 5 min with 1 $\mu \mathrm{L}$ of DpnI enzyme to digest the parental, supercoiled double-stranded DNA. Three microliters of the DpnI-digested PCR mixture was transformed into XL10-Gold ultracompetent cells by following the protocol provided by the kit. The resulting mutant plasmids were verified by DNA sequencing: hDUSP5E264LF, CCTGGTCCACTGTCTGGCTGGGATCTCCCG; hDUSP5E264LR, CGGGAGATCCCAGCCAGACAGTGGACCAGG; hDUSP5E264QF, CAAGGTCCTGGTCCACTGTCAGGCTGGGATC; hDUSP5E264QR, GATCCCAGCCTGACAGTGGACCAGGACCTTG; hDUSP5R214QF, GAATGTCTCCCGACAGACCTCCGAGGCC; hDUSP5R214QR, GGCCTCGGAGGTCTGTCGGGAGACATTC. All constructs were sequence verified prior to protein expression analysis.

Biochemistry, Vol. 55, No. 44 (November 8, 2016): pg. 6187-6195. DOI. This article is @ American Chemical Society and permission has been granted for this version to appear in e-Publications@Marquette. American Chemical Society does not grant permission for this article to be further copied/distributed or hosted elsewhere without the express permission from American Chemical Society. 
Generation and Characterization of the DUSP5 Point Mutant Proteins

Protein expression, GST pull-down assays, and purification protocols were similar to those reported in our previous work on GST-DUSP5 protein. 14 Modifications to the protocol included transfecting final sequenced plasmids into expression competent cells such as Shuffle cells. Shuffle cells are an Escherichia colistrain that allows for the production of proteins with disulfide bonds. We have also produced the mutant proteins in Rosetta2 cells and did not notice much difference in their yields. In addition, under purification and assay conditions, dithiothreitol (DTT) at a final concentration of $1 \mathrm{mM}$ was included, thus ensuring the reduced state of the protein. We also performed mass spectrometry (LCMS/MS) and identified peptides that correspond to the mutant residues in E264Q (38\% coverage) and E264L (46\% coverage). We were unable to detect the R214Q (35\% coverage) peptide. We performed the pERK assay on these mutant proteins as described previously with an incubation time of $20 \mathrm{~min} . \underline{14}$ Because of the presumed degradation products observed in the generated purified protein preparations, the active DUSP5 protein concentration was dependent on the ratio of GST-tagged and untagged DUSP5 to GST in each sample. Ratios were calculated by obtaining band density values from sodium dodecyl sulfate-polyacrylamide gel electrophoresis (SDS-PAGE) gels using ImageJ and then determining the concentration of each component in the sample to identify the total molarity of active DUSP5 in each sample. Western blot membranes were developed using the ChemiDoc Touch Imaging System (Bio-Rad Laboratories, Inc.). Band density values for both pERK and total ERK were similarly quantified using ImageJ. Values for pERK and total ERK were first standardized internally to respective ERK only (no DUSP5) control lanes. Resulting pERK values were then standardized to correlating total ERK values to obtain a standardized ratio used to quantify the relative DUSP5 enzymatic activity. Western blot analysis was performed using standard methods. The DUSP5 antibody was purchased from Abcam (ab53217), and an in-house GST-ECSCR antibody was used for detecting the GSTtagged proteins. The pERK antibody was obtained from Cell Signaling (9106S), while total ERK was purchased from Abcam (ab17942) and Cell Signaling (9102). Rabbit (7074S) and mouse (7076S) IgG HRP-linked secondary antibodies were both purchased from Cell Signaling.

\section{Results and Discussion}

Molecular Dynamics Simulations of the DUSP5 PD

Biochemistry, Vol. 55, No. 44 (November 8, 2016): pg. 6187-6195. DOI. This article is @ American Chemical Society and permission has been granted for this version to appear in e-Publications@Marquette. American Chemical Society does not grant permission for this article to be further copied/distributed or hosted elsewhere without the express permission from American Chemical Society. 
To understand the origin of the low catalytic efficiency of DUSP5, which was evident from the comparison of $k_{\text {cat }}$ values of various DUSPs (Table S1), we performed a visual inspection of the active sites of DUSP5 and DUSP6 available from the X-ray crystal structures of these proteins (PDB entries $\underline{2 \mathrm{G}_{6} \mathrm{Z}^{16}}$ and $\underline{1 \mathrm{MKP}}, \underline{17}$ respectively). In both crystal structures, the active site is occupied by an anion [sulfate in the case of DUSP5 and chloride in the case of DUSP6 (see Figure 2)], and stabilization of such a complex likely involves the same polar and/or electrostatic interactions that are present in the complex between the active site and phosphorylated substrate. Visual inspection of the structural composition of the reaction centers of DUSP5 and DUSP6 (shown as yellow circles in Figure 2) demonstrated their overall similarity, and in both cases, the anion in the active site was stabilized by the $\mathrm{N}-\mathrm{H}$ bonds of the backbones of amino acids at positions +1 to +5 with respect to the catalytic cysteine, as well as by the positively charged guanidinium group of arginine at position +6 (see the primary amino acid sequences in Table 1 ). At the same time, unlike DUSP6, the DUSP5 PD has in the proximity (7.3 $\AA$ ) of the reaction center a secondary binding site (shown by the orange circle in Figure 2A), which stabilizes the anionic ligand by positively charged arginines R213, R214, and R269.
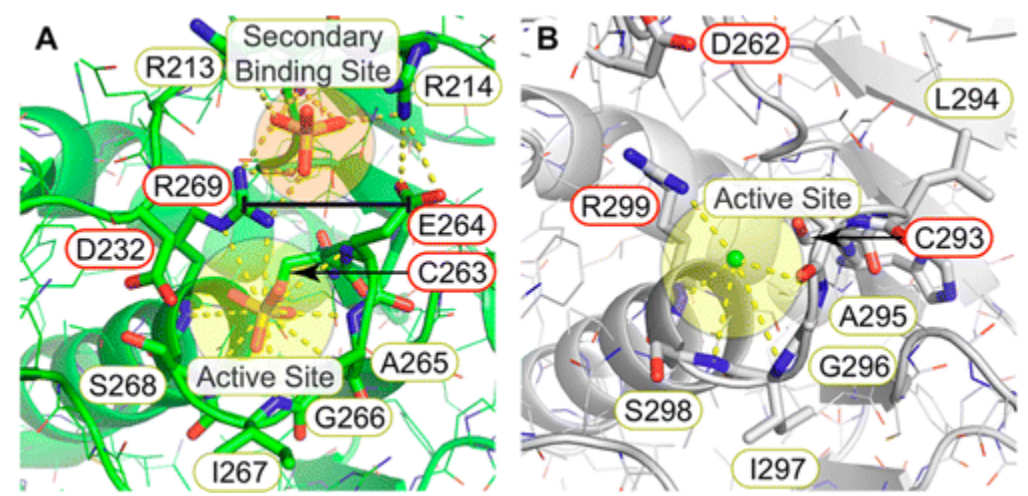

Figure 2. Spatial composition of the active sites of the phosphatase domains of (A) DUSP5 16 and (B) DUSP6. 17

The proximity of the secondary binding site and active site in DUSP5 PD led us to hypothesize that the loading state of the secondary binding site could regulate the activity of the phosphatase domain, i.e., that it could act as an allosteric site. Following this conjecture, we performed two series of MD simulations of the DUSP5 PD, with the secondary binding site being loaded or unloaded by sulfate anion while the active site was sulfate-loaded in both cases. $\underline{28}$ The overall 400 ns MD simulations (see Table S2 for MD details) of the PD with the loaded secondary binding site did not show any significant rearrangement of the active site with respect to the original X-ray structure (Figure 2A). It was found that glutamic acid E264 was turned outward from the reaction center and

Biochemistry, Vol. 55, No. 44 (November 8, 2016): pg. 6187-6195. DOI. This article is @ American Chemical Society and permission has been granted for this version to appear in e-Publications@Marquette. American Chemical Society does not grant permission for this article to be further copied/distributed or hosted elsewhere without the express permission from American Chemical Society. 
stabilized by the salt bridge interaction with a noncatalytic arginine residue R214, while the separation between E264 and R269 of 6-7 Å was indicative of the lack of interaction between them (Figure 3A). At the same time, similar MD simulations (see Table S2) with an unloaded secondary binding site strongly indicated a major change in the salt bridge topology that involved both the active and secondary binding sites. Specifically, E264 not only retained a close contact with R214 but also formed a salt bridge with catalytic arginine R269 (see the histogram in Figure 3B).
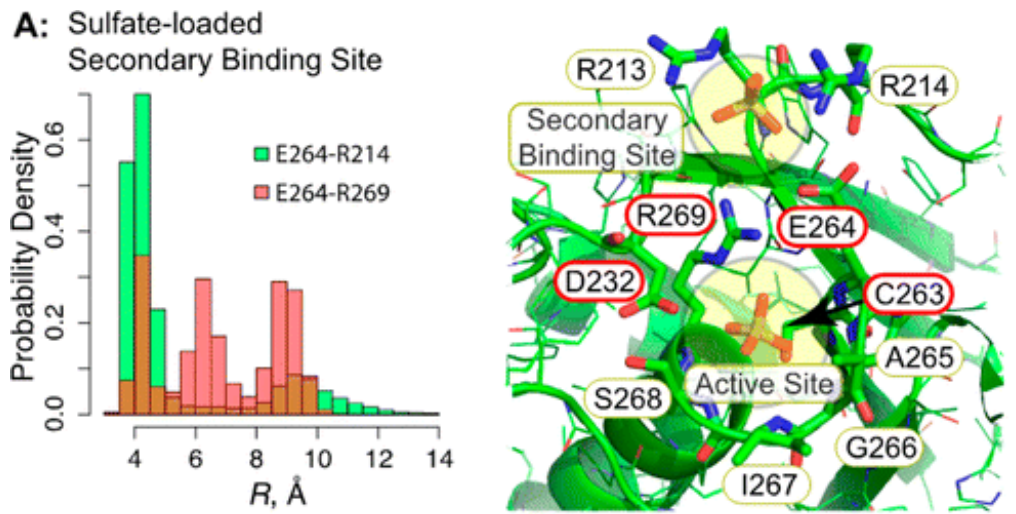

B: Sulfate-unloaded Secondary Binding Site
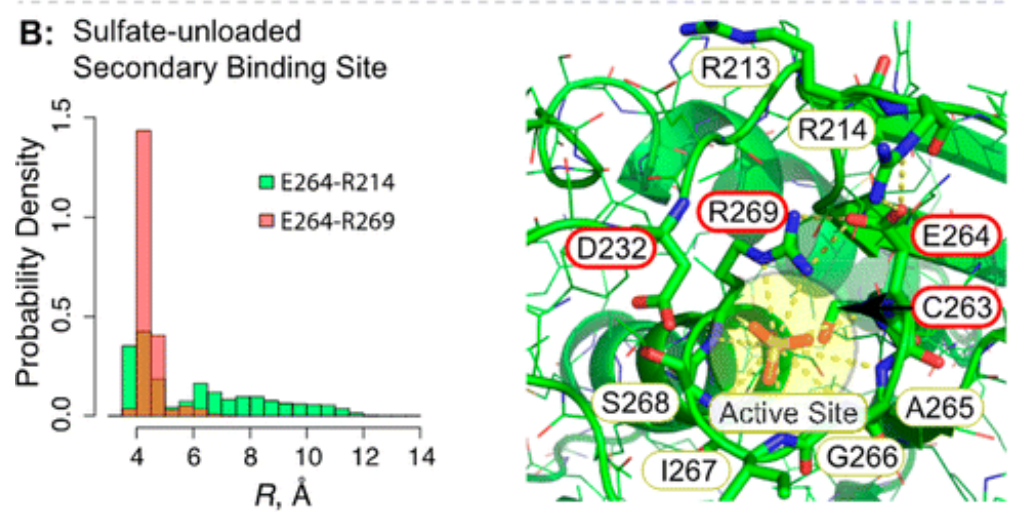

Figure 3. Histograms of the distances between the carboxyl and guanidinium carbons of E264 and R269 (red bars) and E264 and R214 (green bars) shown together with representative PD structures for the case of (A) sulfate-loaded and (B) sulfate-unloaded secondary binding sites (the active site was sulfateloaded in both cases). See Figure S2 for the corresponding time course plots of the E264-R269 distances.

Formation of the salt bridge between E264 and R269 partially obstructs the active site of the DUSP5 PD and thus decreases its binding affinity for a phosphorylated substrate. Furthermore, the involvement of the guanidinium group of R269 in a salt bridge weakens its ability to stabilize the transition state of phosphoryl transfer (see Figure 1). Thus, formation of the E264-R269 salt bridge in the case of the unloaded secondary binding site is expected to decrease the reactivity of DUSP5.

Biochemistry, Vol. 55, No. 44 (November 8, 2016): pg. 6187-6195. DOI. This article is (c) American Chemical Society and permission has been granted for this version to appear in e-Publications@Marquette. American Chemical Society does not grant permission for this article to be further copied/distributed or hosted elsewhere without the express permission from American Chemical Society. 
Interestingly, the presence of two phosphate groups (pThr185 and pTyr187) in the activation loop of pERK2 (natural substrate for DUSP5) allows for the occupation of both the reaction active site and secondary binding site. As the active site is partially obstructed by the salt bridge between E264 and R269 residues, the initial binding event is more likely to occur at the secondary binding site. According to the analysis presented above, such a placement of the anion in the secondary binding site could break the salt bridge between E264 and R269 and thus make the active site accessible for the placement of the second phosphate anion, which is necessary for the formation of the near attack conformation of the DUSP5-pERK2 complex (Figure 4). On the basis of this analysis, we propose that the proximity of the active site and secondary binding site and the presence of the glutamic acid next to the catalytic cysteine might be the unique features of DUSP5 that are essential for controlling its catalytic efficiency and selectivity toward pERK2.

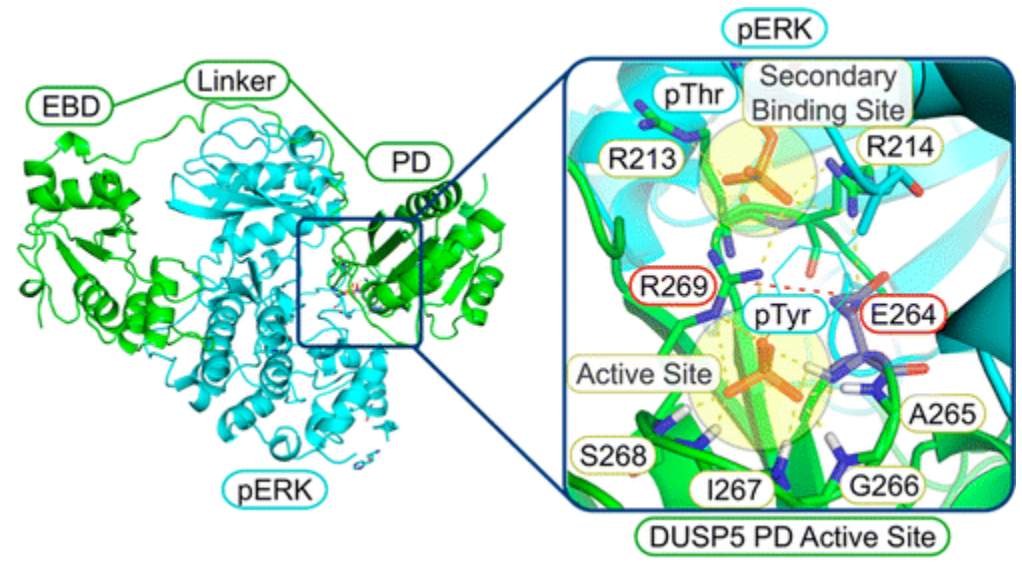

Figure 4. Model structure of the complex of DUSP5 (green) with pERK (cyan). 14

Site-Directed Mutational Analysis Confirms the Importance of the E264 Residue for the Activity of DUSP5 Protein

To validate the MD results, we performed point mutation analysis on the E264 and R214 residues in DUSP5. We mutated E264 to leucine (L) (E264L) and glutamine (Q) (E264Q) and R214 to glutamine (Q) (R214Q) using site-directed mutagenesis. We generated GST-tagged versions of these proteins in bacteria as described in our previous work 14 and purified them on a GST column. Upon expression of these point mutants in bacteria, we noticed three bands on the SDS-PAGE gel for E264Q and R214Q compared to four distinct bands (E264L1-E264L4, from top to bottom, respectively) in the E264L preparations (in Figure 5B, compare lanes E264L and E264Q). In the full length E264L preparation, the E264L1 band was barely detected. On sequencing this band, the E264L mutation was detected in the MS peptides (43\% coverage). For the E264L2 band [ 42 kDa

Biochemistry, Vol. 55, No. 44 (November 8, 2016): pg. 6187-6195. DOI. This article is @ American Chemical Society and permission has been granted for this version to appear in e-Publications@Marquette. American Chemical Society does not grant permission for this article to be further copied/distributed or hosted elsewhere without the express permission from American Chemical Society. 
(Figure 5B, gray arrow)], we obtained 34\% coverage of peptides using MS. For the E264L3 strong $\sim 26 \mathrm{kDa}$ (Figure 5B, red arrow), and E264L4 $22 \mathrm{kDa}$ (Figure 5B, green arrow) bands, the MS coverage was 15\%. We also performed Western blots with the DUSP5 antibody (Figure 5C) and the GST-ECSCR antibody (recognizes GST-tagged proteins) (Figure 5D). With the DUSP5 antibody, the top two bands (E264L1 and E264L2) were visualized, while with the GST-ECSCR antibody, all four bands were visualized. These data collectively argue that the top two bands are GST-E264L proteins while the bottom two bands are GST proteins. Using subsequent purification strategies, we increasingly noticed the $\sim 42 \mathrm{kDa}$ protein with minimal full-length GST-E264L ( $\sim 68 \mathrm{kDa})$ protein (Figure 5, Rosetta 2 expression). In terms of E264Q, we noticed three bands: the expected full-length GST-E264Q band ( $\sim 68 \mathrm{kDa})$, the GST-only band ( $\sim 26 \mathrm{kDa})$, and the weaker, presumably truncated E264Q ( $\sim 2 \mathrm{kDa}$ ) band that cross reacts with both DUSP5 and GST antibodies (Figure 5C,D). These results suggest an instability issue with the E264L fusion protein, and the instability is partly due to the specific mutation because E264Q does not harbor this tendency. Whether conformational changes resulted from the E264L mutation is yet to be determined and could also partially explain this issue. For R214Q preparations, we noticed three bands like E264Q and the top two bands contain DUSP5 protein (Figure 5C, DUSP5 WB) while the bottom band is GST (igure 5D, GST WB).

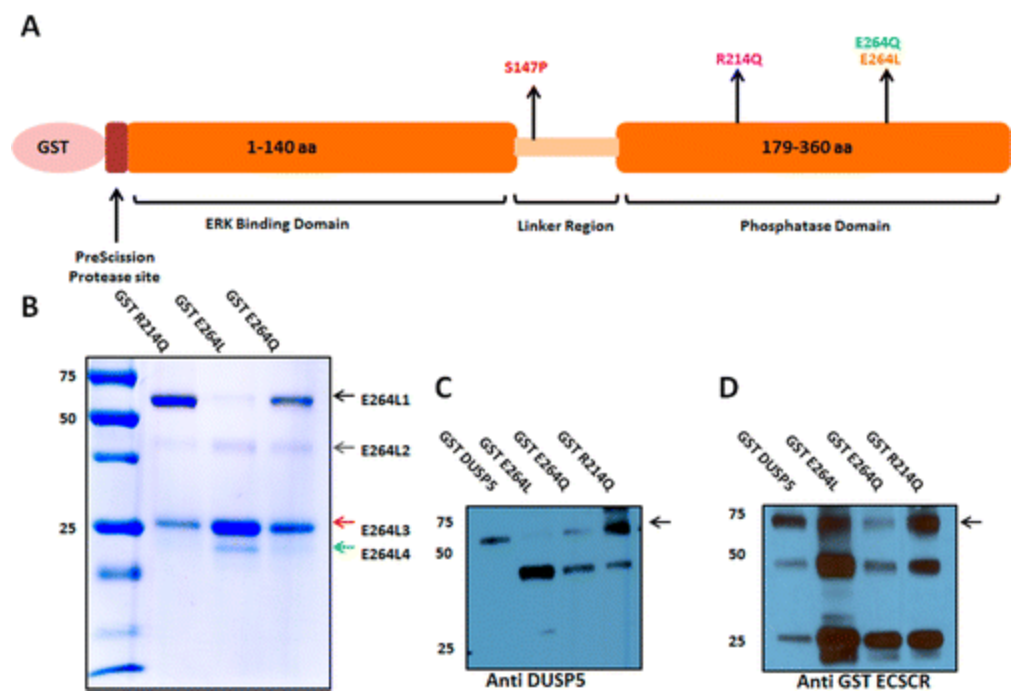

Figure 5. (A) Cartoon depiction of the GST-DUSP5 fusion protein with domains indicated and the amino acids that comprise these domains. The mutations are indicated at the respective location. (B) SDSPAGE gels of the three GST-tagged point mutants after purification on the GST column. The different colored arrows point to the truncated products observed in E264L preparations, which were confirmed by MS. (C and D) Western blots for DUSP5 and GST-ECSCR antibodies with pure proteins indicated in panel B. Each lane included roughly $5 \mu \mathrm{g}$ of pure protein in both SDS-PAGE and Western blots.

Biochemistry, Vol. 55, No. 44 (November 8, 2016): pg. 6187-6195. DOI. This article is @ American Chemical Society and permission has been granted for this version to appear in e-Publications@Marquette. American Chemical Society does not grant permission for this article to be further copied/distributed or hosted elsewhere without the express permission from American Chemical Society. 
Comparisons of Activity among the Three Point Mutants of WT in the pERK Assay

To investigate and compare the activities of the E264L, E264Q, and R214Q proteins to that of WT DUSP5, we first calculated the ratio of the band intensities in the preparations to equalize the total amount of active DUSP5 protein in each preparation. We determined that in E264L preparations, only $17.6 \%$ of the total protein constituted active DUSP5 fractions, compared to 48\% for E264Q and 77\% for WT DUSP5. Therefore, to compare activities across the three proteins in the pERK assay, we set the molarity equal to that of active DUSP5 for each point mutant preparation as explained in Materials and Methods. For the pERK assay, we performed Western blot analysis with purified proteins and ERK as described in Materials and Methods. Three independent experiments were performed with a concentration gradient of WT and mutant proteins ranging from 0.01 to $0.000001 \mathrm{mM}$ in the presence of a constant level of ERK protein $(10 \mathrm{nM})$. For all proteins, we noticed that the loss of pERK was observed in the range between 0.0001 and $0.01 \mathrm{mM}$ DUSP5 protein. Because we observed a sharp cutoff between pERK levels at 0.001 and $0.0001 \mathrm{mM}$ DUSP5 (Figure 6A), we utilized the $0.001 \mathrm{mM}$ values for quantitation, which is described in Materials and Methods. We normalized pERK over total ERK for all three replicates for each protein, and quantification shows that WT and R214Q proteins have activities similar towards pERK while E264Q has 50\% lower pERK levels, implying higher DUSP5 activity, and the E264L mutant exhibits a 36\% increase in pERK levels, implying loss of DUSP5 activity. These results suggest that residue E264 is critical for interaction with the substrate, which in turn influences the activity of the DUSP5 protein.

Biochemistry, Vol. 55, No. 44 (November 8, 2016): pg. 6187-6195. DOI. This article is @ American Chemical Society and permission has been granted for this version to appear in e-Publications@Marquette. American Chemical Society does not grant permission for this article to be further copied/distributed or hosted elsewhere without the express permission from American Chemical Society. 

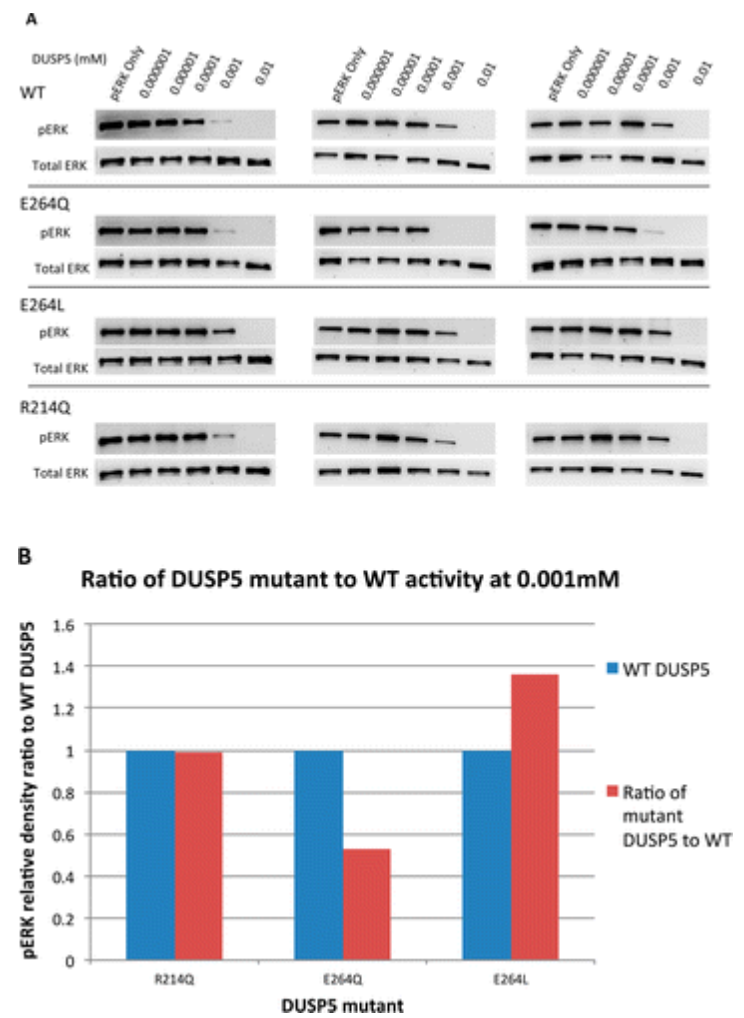

Figure 6. pERK assay. Sets of replicates of the DUSP5 pERK dephosphorylation assay (A) show that identifiable activity against pERK begins at $\sim 0.001 \mathrm{mM}$ DUSP5 protein for all four mutants. These bands were quantified by densitometry and compared to WT values to determine a ratio (B). Lower ratios are due to less phosphorylated ERK present, which is indicative of more enzymatic activity in that mutant relative to WT. All initial pERK values were normalized to respective total ERK densitometry bands to control for variability stemming from loading differences or exposure time during development.

It is noteworthy that we prepared the R214Q point mutation as it was found in DUSP5 in the catalogue of somatic mutations in the cancer (COSMIC) database. This arginine mutation in the secondary binding pocket with the biologically relevant $\mathrm{pERK}$ assay showed activity similar to that of the WT DUSP5 protein (Figure 6). It is noted that the secondary binding pocket contains three arginine residues (i.e., R213, R214, and R269), and mutation of one arginine to a polar residue (R214Q) is expected to have a limited impact on the initial binding of pERK to the secondary binding pocket (vide infra). The computational analysis discussed above showed that the E264-R269 salt bridge partially obstructs the active site of the DUSP5 PD. Thus, it is expected that disrupting the salt bridge by an E264Q or E264L mutation should lead to increased activity of DUSP5, and the observed increase in the activity of the E264Q mutant compared with that of WT DUSP5 further supports the computational finding. Interestingly, however, the disruption of the salt bridge due to the E264L mutation leads to decreased enzymatic activity of the DUSP5 mutant, which may seem somewhat surprising. However, a closer look at the

Biochemistry, Vol. 55, No. 44 (November 8, 2016): pg. 6187-6195. DOI. This article is @ American Chemical Society and permission has been granted for this version to appear in e-Publications@Marquette. American Chemical Society does not grant permission for this article to be further copied/distributed or hosted elsewhere without the express permission from American Chemical Society. 
DUSP5-pERK complex shows that both mutants should facilitate the formation of this complex due to the disruption of the salt bridge. Following the formation of this complex, the side chain of residue 264 (i.e., $\mathrm{E}, \mathrm{Q}$, or L) moves away from the active site and is stabilized by the electrostatic interactions with polar/charged R191 (pERK2), R194 (pERK2), S212 (DUSP5), and R214 (DUSP5) residues (Figure 7). Such a charged/polar environment is clearly beneficial for the stabilization of glutamic acid (E264 WT) or glutamine (E264Q mutant) but not in case of hydrophobic leucine (i.e., in the E264L mutant). Thus, the DUSP5-pERK complex in the E264L mutant is expected to be somewhat destabilized because of the nonpolar nature of leucine L264, which could lead to the overall decrease in the catalytic activity of the E264L DUSP5 mutant.

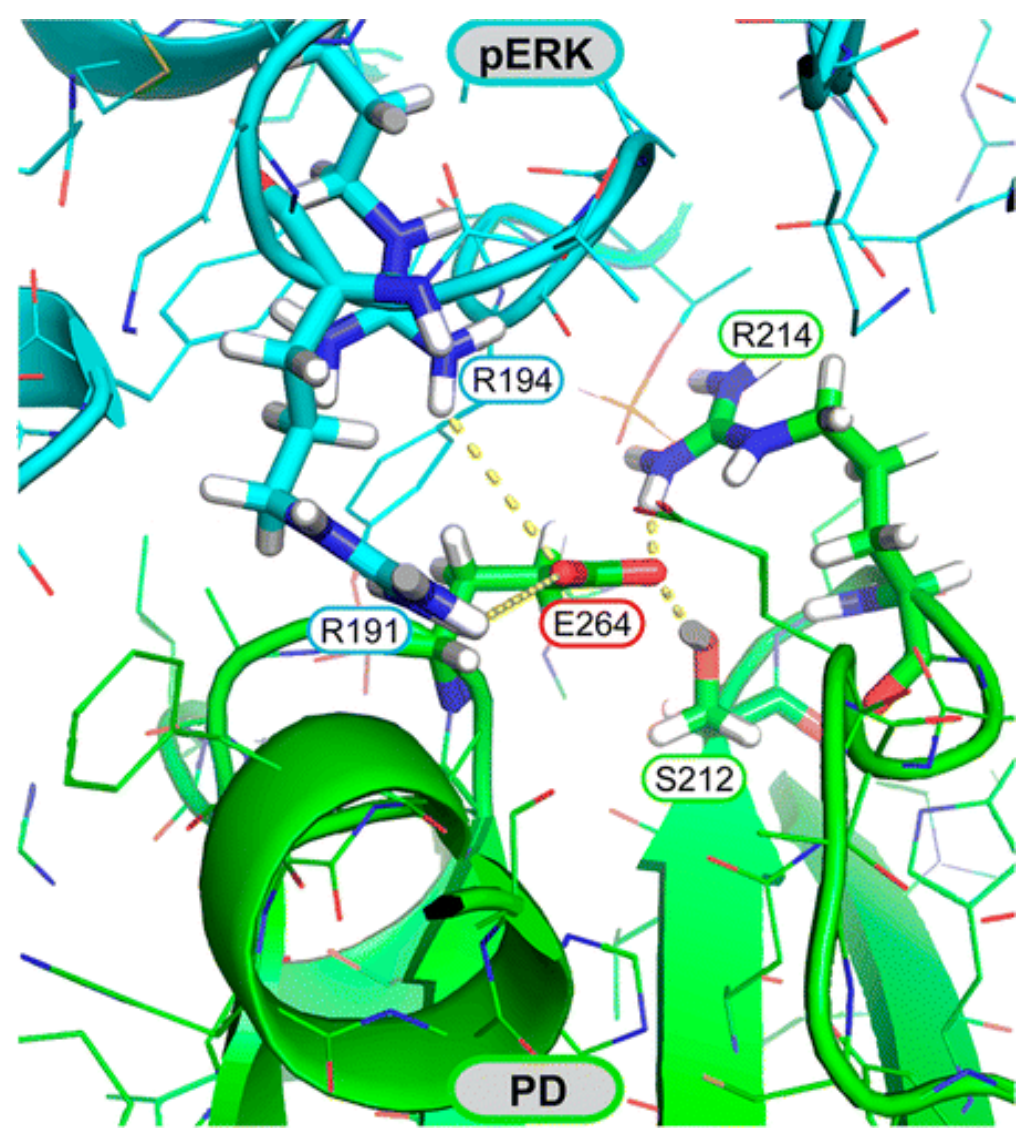

Figure 7. Model structure showing the polar/ionized environment surrounding glutamic acid E264 after the formation of the DUSP5-pERK complex and breaking of the E264-R269 salt bridge.

Biochemistry, Vol. 55, No. 44 (November 8, 2016): pg. 6187-6195. DOI. This article is @ American Chemical Society and permission has been granted for this version to appear in e-Publications@Marquette. American Chemical Society does not grant permission for this article to be further copied/distributed or hosted elsewhere without the express permission from American Chemical Society. 
NOT THE PUBLISHED VERSION; this is the author's final, peer-reviewed manuscript. The published version may be accessed by following the link in the citation at the bottom of the page.

Importance of a Remote Disulfide Linkage for DUSP5 Activity and Loading of the Primary Active Site

The emerging understanding of the link between the reactivity of DUSP5 and the occupation state of the secondary binding site attracted our attention to the fact that the essential constituents of the secondary binding site, i.e., R213 and R214, are located on the same loop between sheets $\beta 3$ and $\beta 4$ of the DUSP5 phosphatase domain (Figure 8A). At the same time, the structurally similar DUSP6 lacks this loop, and its residues between the sheets $\beta 3$ and $\beta 4$ are immobilized within sheet $\beta 4^{\prime}$ (Figure 8B). Moreover, the $\beta 3-\beta 4$ loop of DUSP 5 also contains a cysteine amino acid C219 that is capable of forming a disulfide bridge with C197 (Figure 9). Formation of the S-S bond may reduce the flexibility of the secondary binding site, and on the basis of the discussion above that the initial binding event occurs at the secondary binding site, it is expected that the redox state of the disulfide bridge should affect the activity of DUSP5.

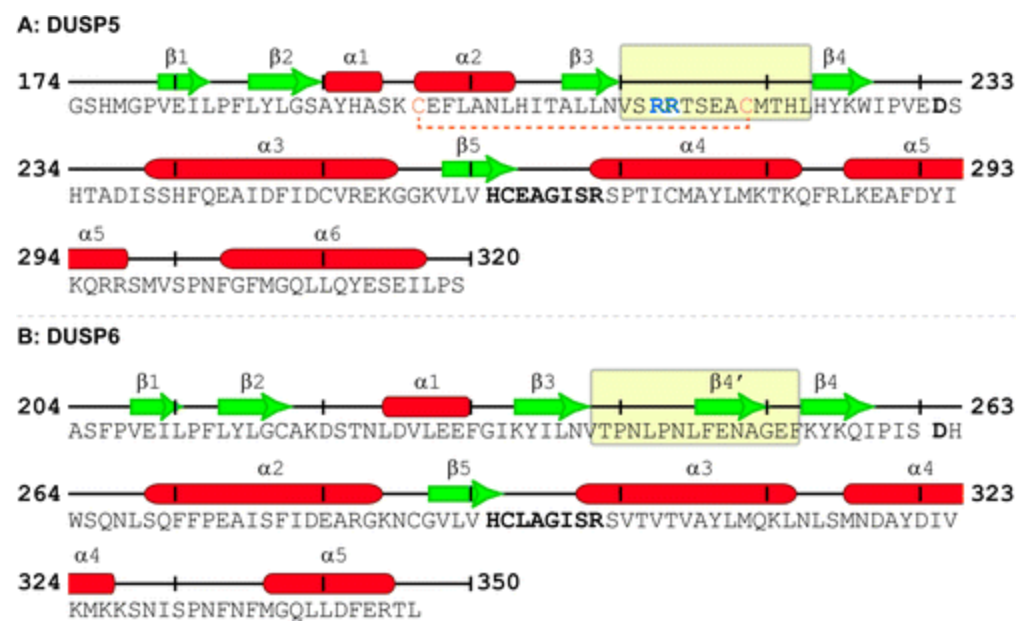

Figure 8. Comparison of the primary and secondary structures of the phosphatase domains of $(A)$ DUSP5 and (B) DUSP6.

To improve our understanding of the interplay between the redox state of DUSP5 and its reactivity, we performed a comparative molecular dynamics study of the disulfide and dithiol states of the DUSP5 PD based on the available X-ray structure. The overall 400 ns MD simulations (see Table S2) of the PD in the disulfide state revealed that the secondary binding site mostly exists in one conformation (Figure 9A) in which the anion in the secondary binding site is fully stabilized by R213, R214, and R269 amino acid residues close $(\sim 7 \AA)$ to the anion-bound active site (Figure 9C).

Biochemistry, Vol. 55, No. 44 (November 8, 2016): pg. 6187-6195. DOI. This article is @ American Chemical Society and permission has been granted for this version to appear in e-Publications@Marquette. American Chemical Society does not grant permission for this article to be further copied/distributed or hosted elsewhere without the express permission from American Chemical Society. 
NOT THE PUBLISHED VERSION; this is the author's final, peer-reviewed manuscript. The published version may be accessed by following the link in the citation at the bottom of the page.
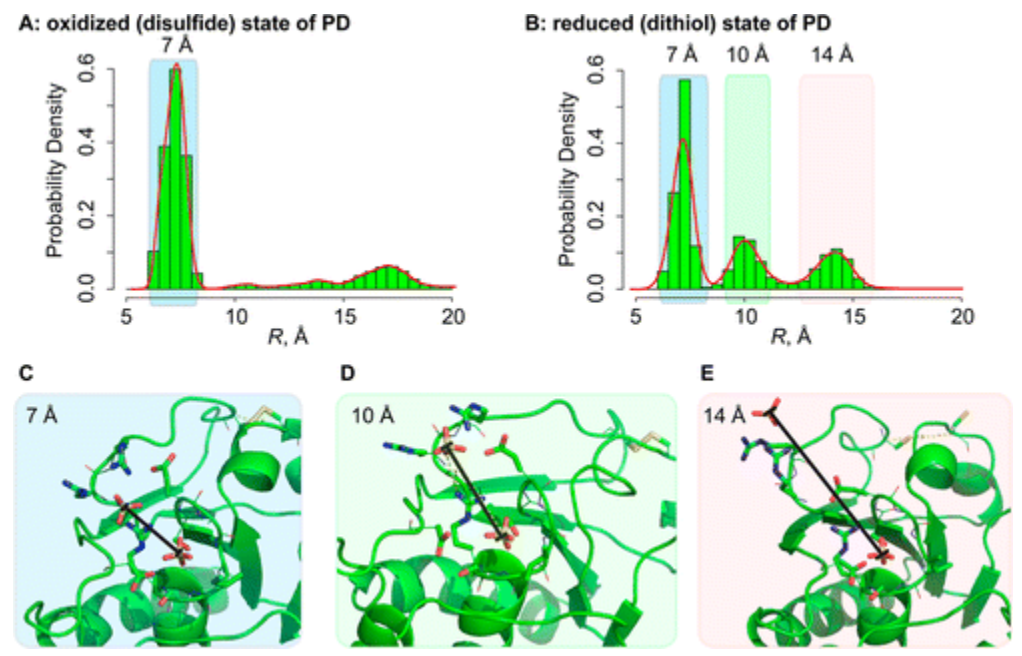

Figure 9. Distribution of the distance between the sulfur atoms of the sulfate anions in the (A) disulfide and (B) dithiol forms of the DUSP5 PD, obtained by MD simulations. (C and D) Representative structures of the disulfide form of the DUSP5 PD that correspond to the distribution maxima at 7 and $10 \AA$, respectively. (E) Representative structure of the dithiol form of the DUSP5 PD that corresponds to the distribution maximum at $\sim 14 \AA$ (see panel B).

The overall 400 ns MD simulations (see Table S2), performed in a similar manner for the dithiol state of the PD, reproduced the existence of the previously found conformer and also located two more conformers (Figure 9B). In one of these conformations, the anion at the secondary binding site is located farther from the active site anion $(\sim 10 \AA)$ and is stabilized by only R213 and R214 residues (Figure 9D). In the other binding mode, R213 and R214 form a salt bridge complex with the sulfate anion lying outside the secondary binding site [ 14 A from the anion in the active site (see Figure 9E)]. The identification of this binding regime might be highly relevant to the initial contact between DUSP5 and pERK, where it can serve to capture the phosphothreonine anion of pERK and help orient the PD of DUSP5 and pERK to a pre-reactive conformation. The latter binding modes seem to be more characteristic of the dithiol (i.e., reduced) form of DUSP5, which therefore could be expected to be more reactive than the corresponding disulfide (i.e., oxidized) form. This hypothesis was verified experimentally by observation of a 2 -fold increase in DUSP5 phosphatase activity under reducing conditions, i.e., in the presence of dithiothreitol, which breaks the C197-C219 disulfide bond. 14 It is further noted that nuclear DUSP5 is expected to be present in a reducing environment under normal conditions where it functions in a more catalytically active dithiol state; $\underline{29}$ however, the oxidized/disulfide state of DUSP5 might also be of biological relevance under certain circumstances, e.g., in abnormal cells.

Biochemistry, Vol. 55, No. 44 (November 8, 2016): pg. 6187-6195. DOI. This article is @ American Chemical Society and permission has been granted for this version to appear in e-Publications@Marquette. American Chemical Society does not grant permission for this article to be further copied/distributed or hosted elsewhere without the express permission from American Chemical Society. 


\section{Conclusions}

The detailed molecular modeling of the DUSP5-pERK2 complex showed that the pair of phosphate groups in pERK2 resides in the active site and secondary binding site pockets. The positioning of the phosphate groups in the DUSP5-pERK2 complex closely resembles the positioning of the pair of sulfate anions in the binding pockets of the DUSP5 PD X-ray structure. The MD simulations showed that the active site in DUSP5 is partially obstructed because of the presence of a salt bridge between residues E264 and R269 (Figure 10). Thus, an initial occupation of the secondary binding site by phosphorylated threonine T185 should lead to the breakage of the salt bridge, which then allows the occupation of the active site by phosphorylated tyrosine Y187 of pERK2 (Figure 10).

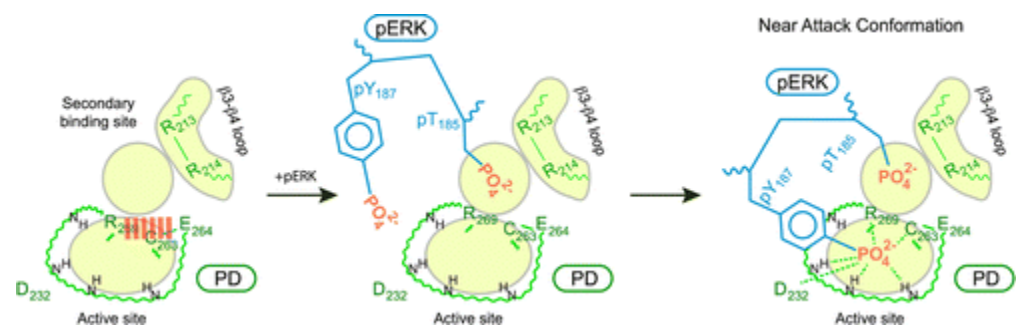

Figure 10. Schematic representation of the binding of pERK and the PD of DUSP5 leading to the prereactive near attack conformation.

The allosteric mechanism of formation of the DUSP5-pERK pre-reactive complex, presented in Figure 10, identifies E264 as a critical residue involved in salt bridge formation. The preparation of the point mutation of E264 to glutamine (E264Q), which maintains the structure of the DUSP5-pERK complex while disrupting the salt bridge, leads to a predicted increase in the enzymatic activity of mutant DUSP5 toward pERK2 compared to that of WT DUSP5. The critical role of the secondary binding site in the formation of the DUSP5-pERK pre-reactive complex was further demonstrated by the involvement of a remote disulfide linkage, which controls the structure of the secondary binding pocket based on its redox state and, in turn, the enzymatic activity of DUSP5. It is expected that characterization of the mechanism of DUSP5 reactivity toward pERK will aid our ongoing effort directed at the development of its small-molecule inhibitors.

\section{Supporting Information}

The Supporting Information is available free of charge on the ACS Publications website at DOI: $10.1021 /$ acs.biochem.6b00498.

Biochemistry, Vol. 55, No. 44 (November 8, 2016): pg. 6187-6195. DOI. This article is @ American Chemical Society and permission has been granted for this version to appear in e-Publications@Marquette. American Chemical Society does not grant permission for this article to be further copied/distributed or hosted elsewhere without the express permission from American Chemical Society. 
NOT THE PUBLISHED VERSION; this is the author's final, peer-reviewed manuscript. The published version may be accessed by following the link in the citation at the bottom of the page.

- Comparison of the reported Michaelis-Menten parameters for various DUSPs using the $p$-nitrophenyl phosphate assay and MD simulation details ( $\underline{\mathrm{PDF}})$

\section{Funding Information}

R. Ramchandran is the recipient of a National Institutes of Health (NIH) Vascular Interventions/Innovations and Therapeutic Advances (VITA) award (BAA-NHLBI-CSB-HV-2013-02-JS). R. Ramchandran also is partly supported by NIH Grants HL123338, HL102745, and HL112639. M.L. and R. Ramchandran are supported partly by Woman's Health Research Program funds from the Department of Obstetrics and Gynecology at the Medical College of Wisconsin and the Department of Pediatrics. D.S.S. is partly supported by NIH Grants AI101975 and HL112639. R. Rathore is partly supported by National Science Foundation (NSF) Grant CHE-1508677. The calculations were performed on the high-performance computing cluster Père at Marquette University funded by NSF Grants OCI0923037 and CBET-0521602, and the Extreme Science and Engineering Discovery Environment (XSEDE) funded by the NSF (TG-CHE130101).

The authors declare no competing financial interest.

\section{Acknowledgment}

We thank members of the Developmental Vascular Biology Program for their invaluable input and insight during the course of this study.

\section{References}

1 Widmann, C., Gibson, S., Jarpe, M. B., and Johnson, G. L. (1999) Mitogen-Activated Protein Kinase: Conservation of a Three-kinase Module from Yeast to Human Physiol. Rev. 79, 143- 180

2Raman, M., Chen, W., and Cobb, M. H. (2007) Differential Regulation and Properties of MAPKs Oncogene 26, 3100- 3112 DOI: 10.1038/sj.onc.1210392

3BBoutros, T., Chevet, E., and Metrakos, P. (2008) Mitogen-Activated Protein (MAP) Kinase/MAP Kinase Phosphatase Regulation: Roles in Cell Growth, Death, and Cancer Pharmacol. Rev. 60, 261- 310 DOI: $10.1124 /$ pr.107.00106

4 Camps, M., Nichols, A., Gillieron, C., Antonsson, B., Muda, M., Chabert, C., Boschert, U., and Arkinstall, S. (1998) Catalytic Activation of the Phosphatase MKP-3 by ERK2 Mitogen-Activated Protein Kinase Science 280, 1262-1265 DOI: 10.1126/science.280.5367.1262

5Farooq, A. and Zhou, M.-M. (2004) Structure and regulation of MAPK phosphatases Cell. Signalling 16, 769- 779 DOI: 10.1016/j.cellsig.2003.12.008

6Huang, C.-Y. and Tan, T.-H. (2012) DUSPs, to MAP Kinases and Beyond Cell Biosci. 2, 24 DOI: 10.1186/2045-3701-2-24

7Caunt, C. J. and Keyse, S. M. (2013) Dual-Specificity MAP Kinase Phosphatases (MKPs): Shaping the Outcome of MAP Kinase Signalling FEBS J. 280, 489- 504 DOI: 10.1111/j.17424658.2012.08716.x

Biochemistry, Vol. 55, No. 44 (November 8, 2016): pg. 6187-6195. DOI. This article is C American Chemical Society and permission has been granted for this version to appear in e-Publications@Marquette. American Chemical Society does not grant permission for this article to be further copied/distributed or hosted elsewhere without the express permission from American Chemical Society. 
NOT THE PUBLISHED VERSION; this is the author's final, peer-reviewed manuscript. The published version may be accessed by following the link in the citation at the bottom of the page.

8Denu, J. M. and Dixon, J. E. (1995) A Catalytic Mechanism for the Dual-Specific Phosphatases Proc. Natl. Acad. Sci. U. S. A. 92, 5910- 5914 DOI: 10.1073/pnas.92.13.5910

9Note that distributions among non-, mono-, and diphosphorylated forms of ERKs are cell- and ligandspecific. See: Iwamoto, N., D’Alessandro, L. A., Depner, S., Hahn, B., Kramer, B. A., Lucarelli, P., Vlasov, A., Stepath, M., Böhm, M. E., Deharde, D., Damm, G., Seehofer, D., Lehmann, W. D., Klingmüller, U., and Schilling, M. (2016) Context-specific flow through the MEK/ERK module produces cell- and ligand-specific patterns of ERK single and double phosphorylation Sci. Signaling 9, ra13 D0I: 10.1126/scisignal.aab1967

10 Pramanik, K., Chun, C. Z., Garnaas, M. K., Samant, G. V., Li, K., Horswill, M. A., North, P. E., and Ramchandran, R. (2008) Dusp-5 and Snrk-1 coordinately function during vascular development and disease Blood 113, 1184- 1191 DOI: 10.1182/blood-2008-06-162180

11Mandl, M., Slack, D. N., and Keyse, S. M. (2005) Specific Inactivation and Nuclear Anchoring of Extracellular Signal-Regulated Kinase 2 by the Inducible Dual-Specificity Protein Phosphatase DUSP5 Mol. Cell. Biol. 25, 1830- 1845 DOI: 10.1128/MCB.25.5.1830-1845.2005

$\underline{12}$ Kucharska, A., Rushworth, L. K., Staples, C., Morrice, N. A., and Keyse, S. M. (2009) Regulation of the Inducible Nuclear Dual-Specificity Phosphatase DUSP5 by ERK MAPK Cell. Signalling21, 17941805 DOI: 10.1016/j.cellsig.2009.07.015

13 Roskoski, R. (2012) ERK1/2 MAP Kinases: Structure, Function, and Regulation Pharmacol. Res. 66, 105- 143 DOI: $10.1016 /$ j.phrs.2012.04.005

14 Nayak, J., Gastonguay, A. J., Talipov, M. R., Vakeel, P., Span, E. A., Kalous, K. S., Kutty, R. G., Jensen, D. R., Pokkuluri, P., Sem, D. S., Rathore, R., and Ramchandran, R. (2014) Protein Expression, Characterization and Activity Comparisons of Wild Type and Mutant DUSP5 Proteins BMC Biochem. 15, 27 DOI: 10.1186/s12858-014-0027-0

15Peti, W. and Page, R. (2013) Molecular Basis of MAP Kinase Regulation Protein Sci. 22, 1698- 1710 DOI: $10.1002 /$ pro.2374

16Jeong, D. G., Cho, Y. H., Yoon, T.-S., Kim, J. H., Ryu, S. E., and Kim, S. J. (2007) Crystal Structure of the Catalytic Domain of Human DUSP5, a Dual Specificity MAP Kinase Protein Phosphatase Proteins: Struct., Funct., Genet. 66, 253- 258 DOI: 10.1002/prot.21224

17Stewart, A. E., Dowd, S., Keyse, S. M., and McDonald, N. Q. (1999) Crystal Structure of the MAPK Phosphatase Pyst1 Catalytic Domain and Implications for Regulated Activation Nat. Struct. Biol. 6, 174- 181 DOI: $10.1038 / 5861$

18Farooq, A., Plotnikova, O., Chaturvedi, G., Yan, S., Zeng, L., Zhang, Q., and Zhou, M.-M. (2003) Solution Structure of the MAPK Phosphatase PAC-1 Catalytic Domain. Insights Into Substrate-Induced Enzymatic Activation of MKP Structure 11, 155- 164 DOI: 10.1016/S0969-2126(02)00943-7

19 Jeong, D. G., Jung, S.-K., Yoon, T.-S., Woo, E.-J., Kim, J. H., Park, B. C., Ryu, S. E., and Kim, S. J. (2009) Crystal Structure of the Catalytic Domain of Human MKP-2 Reveals a 24-mer Assembly Proteins: Struct., Funct., Genet. 76, 763- 767 DOI: 10.1002/prot.22423

20Almo, S. C., Bonanno, J. B., Sauder, J. M., Emtage, S., Dilorenzo, T. P., Malashkevich, V., Wasserman, S. R., Swaminathan, S., Eswaramoorthy, S., Agarwal, R., Kumaran, D., Madegowda, M., Ragumani, S., Patskovsky, Y., Alvarado, J., Ramagopal, U. A., Faber-Barata, J., Chance, M. R., Sali, A., Fiser, A., Zhang, Z.-Y., Lawrence, D. S., and Burley, S. K. (2007) Structural Genomics of Protein Phosphatases J. Struct. Funct. Genomics 8, 121- 140 DOI: 10.1007/s10969-007-9036-1

Biochemistry, Vol. 55, No. 44 (November 8, 2016): pg. 6187-6195. DOI. This article is @ American Chemical Society and permission has been granted for this version to appear in e-Publications@Marquette. American Chemical Society does not grant permission for this article to be further copied/distributed or hosted elsewhere without the express permission from American Chemical Society. 
211Krieger, E., Joo, K., Lee, J., Lee, J., Raman, S., Thompson, J., Tyka, M., Baker, D., and Karplus, K. (2009) Improving Physical Realism, Stereochemistry, and Side-Chain Accuracy in Homology Modeling: Four Approaches That Performed Well in CASP8 Proteins: Struct., Funct., Genet. 77, 114- 122 DOI: $10.1002 /$ prot.22570

22 Krieger, E., Koraimann, G., and Vriend, G. (2002) Increasing the Precision of Comparative Models with YASARA NOVA—a Self-Parameterizing Force Field Proteins: Struct., Funct., Genet. 47, 393- 402 DOI: $10.1002 /$ prot.10104

23Duan, Y., Wu, C., Chowdhury, S., Lee, M. C., Xiong, G., Zhang, W., Yang, R., Cieplak, P., Luo, R., Lee, T., Caldwell, J., Wang, J., and Kollman, P. (2003) A Point-Charge Force Field for Molecular Mechanics Simulations of Proteins Based on Condensed-phase Quantum Mechanical Calculations J. Comput. Chem. 24, 1999- 2012 DOI: 10.1002/jcc.10349

24Essmann, U., Perera, L., Berkowitz, M. L., Darden, T., Lee, H., and Pedersen, L. G. (1995) A Smooth Particle Mesh Ewald Method J. Chem. Phys. 103, 8577- 8593 D0I: 10.1063/1.470117

25 Jorgensen, W. L., Chandrasekhar, J., Madura, J. D., Impey, R. W., and Klein, M. L. (1983) Comparison of Simple Potential Functions for Simulating Liquid Water J. Chem. Phys. 79, 926- 935 DOI: $10.1063 / 1.445869$

26Krieger, E. and Vriend, G. (2015) New ways to boost molecular dynamics simulations J. Comput. Chem. 36, 996- 1007 DOI: $10.1002 /$ jcc.23899

27-Krieger, E., Darden, T., Nabuurs, S. B., Finkelstein, A., and Vriend, G. (2004) Making Optimal Use of Empirical Energy Functions: Force-field Parameterization in Crystal Space Proteins: Struct., Funct., Genet. 57, 678- 683 DOI: 10.1002/prot.20251

28 Similar results were obtained for the case in which the active site was not occupied by an anion. $\underline{29}$ Go, Y.-M. and Jones, D. P. (2010) Redox Control Systems in the Nucleus: Mechanisms and Functions Antioxid. Redox Signaling 13, 489- 509 DOI: 10.1089/ars.2009.3021

Biochemistry, Vol. 55, No. 44 (November 8, 2016): pg. 6187-6195. DOI. This article is @ American Chemical Society and permission has been granted for this version to appear in e-Publications@Marquette. American Chemical Society does not grant permission for this article to be further copied/distributed or hosted elsewhere without the express permission from American Chemical Society. 